\title{
小児精索静脈瘤の臨床的検討
}

\begin{tabular}{|c|c|c|c|c|}
\hline \multirow[t]{3}{*}{$\begin{array}{l}\text { 東京厚生年金病院泌尿器科 } \\
\text { (主任：三橋慎一部長) }\end{array}$} & 川 & 村 & 健 & $=$ \\
\hline & 角 & 谷 & 秀 & \\
\hline & 片 & 海 & 善 & \\
\hline \multirow{4}{*}{ 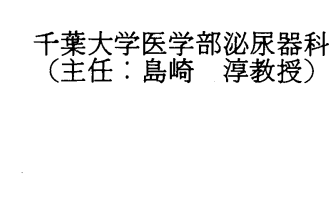 } & 布 & 施 & 秀 & \\
\hline & 宮 & 内 & 大 & \\
\hline & 伊 & 藤 & 晴 & \\
\hline & 島 & 崎 & & 淳 \\
\hline
\end{tabular}

\section{CLINICAL STUDY OF VARICOCELE IN SCHOOLBOYS}

\author{
Kenji Kawamura \\ Department of Urology, Tokyo Kosei Nenkin Hospital \\ (Director: Dr. S. Mitsuhashi) \\ Hidenori Sumiya, Zengo Kataumi, Hideki Fuse, Taisei Miyauchi \\ Haruo Ito and Jun Shimazaki \\ Department of Urology, School of Medicine, Chiba University \\ (Director : Prof. J. Shimazaki)
}

Clinical study was made of 20 patients with varicocele under 18 years of age. The following results were obtained.

1. The varicocele was left-sided in 19 patients and bilateral in 1 . High ligation of the left internal spermatic vein was carried out in all cases.

2. The volume of the left testicle was significantly smaller than that of the right testicle.

3. Bilateral biopsy was performed in 12 . Spermatogenesis was generally reduced in the left testicle, although there was no significant difference between the right and left testicles.

4. We believe that surgical removal of a varicocele shoud be carried out in the childhood as soon as possible in order to prevent the danger of progressive damage of the spermatogenesis of the testicle.

要旨：18歳以下にみられた精索静脈瘤20例について臨床的研究をおこない, 次のような結果を得た。

1. 1 例に両側例がみられた他はすべて左側であり, 全例に左内精静脈高位結紮術を行った.

2. 辠丸の大きさは患側である左側が右側に比べ, 有意に小さかった。

3，睪丸組織所見は有意の差は得られなかったが，右側に比べ左側で造精機能が低下している例が多 かった.

4. 小児期に抢ける精索静脈瘤は, 将来の造精機能の低下につながることが考えられ，また症状をもつ ものが多いことより，発見されたものは手術的に治療すべきものと考兄られた。

\section{はじめに}

精索静脈瘤は, 男子不妊症の原因疾患とされ ${ }^{11}$, 最近 注目をあびているが，小児の本症は従来よりまれなも のとされ，あまり重要視されていなかった。しかし小 児期に発生するものは, 罹病期間がながく, 造精機能 に対する影響も大きなものがあると考兄られる。また
頻度も従来考えられたほどまれなものではないとさ れ，小児の本症は重要な疾患と思われる。我々は小児 にみられた精索静脈瘤について臨床的研究を行った。

対象と方法

対象は, 1979年より1984年末むでに，千葉大学泌尿 器科を受診し，精索静脈瘤の発見されたもののうち18 
歳以下の 20 例である。

診断は立位にて腹圧を加えた状態で，視診および触

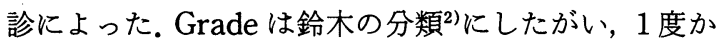
ら 3 度に分けた。鼻丸体積は陰囊皮膚上よりノギスを もちいて 3 方向測定し, Lambert の式帛により,

緃 $\times$ 横 $\times$ 幅 $\times 0.71=$ 体積

\section{として計算した。}

術前 6 例に IVP を施行した. 全例に内精静脈高位結 禁術を施行した。術式は Palomo 法年に準じた。手術時 13例に両側辠丸生検を打こない，Bouin 液にて固定し H-E 染色した。辠丸組織の各精細管 1 個当たりの精祖 細胞を測定した。 また Jonsen の score count 法5)を用 い造精機能状態をみた。

年長者の 4 例については，精液検査を行った。採取 は用手法により, 精液量, 精子濃度, 精子運動率を測 定した。

\section{結 果}

年齢は 9 歳より 18 歳であり，12歳と15歳がそれぞれ 5 例ずつと最も多く, 平均年齢は 14.0 歳であった。主 訴は左陰囊腫大がもっとも多く 15 例, 75\%を占めた. 疼痛を認めたものは少なく, 陰囊痛, 陰襄不快感各 1 例であった，頻尿，排尿痛など本症と直接関係ないと 思われる主訴も各 1 例ずつみられた。 また 1 例に，患 側の䁄丸が対側に比べて小さいことを主訴として来院
した例があった。患側は19例で左側であり，両側例が 1 例であった. Grade は両側例の 1 例をふくめた 4 例 が 2 度であり，その他はすべて 3 度であった。

発見より受診までの期間は, 最短 1 カ月最長 4 年で あり，かなりばらつきがみられ，平均は， 1 年 4 カ月 であった。既往歴は, 腎孟腎炎, 膀胱炎, ソヶイヘル ニア, 副辠丸炎, 血精液症が各 1 例にみられたが, 特 に本症と関係があると思われるものはみられなかっ た. IVPは 6 例に施行したがいずれも異常はみられな かった，肉眼的血尿をきたしたものはなかった，尿沈 査を 10 例に施行したが, このらち赤血球 10 個以上/各視 野の顕微鏡的血尿がみられたのは 1 例だけであった (表 1 ).

17例で辠丸の大きさを測定した. 左右の比較では, 症例19は右副鼻丸炎によると思われる萎縮がみられ， これを除く16例のうち，13例は右が左より大きく，3 例では左の方が右より大きかった. 左右差を paired t検定でみると, $\mathrm{p}<0.05$ で有意に左が小さかった（表 2).

辠丸生検での精祖細胞数の比較では, 左より右の方 が多いもの 7 例, 左の方が多いもの 4 例であった（n. s.). Jonsen の scoure count 法でみると, 右の方が高 いもの 5 例, 左の方が高いもの 4 例であり, ほぼ同じ であったもの 3 例であり, 有意の差はみられなかった

表 1 症例一覧

\begin{tabular}{|c|c|c|c|c|c|c|c|}
\hline 症例 & 年齢 & 主 訴 & Grade & 受診迄の期間 & 既往歴 & IVP & 血尿 \\
\hline 1 & 9 & 左蔁丸が小 & 左 2 & 1 か月 & & & \\
\hline 2 & 11 & 左陰襄腫大 & 左 3 & 8 か月 & & 正常 & 無 \\
\hline 3 & 12 & 左陰霊不快感 & 左 3 & 1 年 & & & 有 \\
\hline 4 & 12 & 左陰震腫大 & 左 2 & 1 年10か月 & 左鼠怪ヘルニア & & 無 \\
\hline 5 & 12 & 左陰囊腫大 & 左 3 & 4 年 & アレルギー鼻炎 & & \\
\hline 6 & 12 & 左陰囊腫大 & 左 3 & 9 か月 & & & 無 \\
\hline 7 & 12 & 左陰雯腫大 & 左 3 & 1 年 & & & \\
\hline 8 & 13 & 左陰囊腫大 & 左 3 & 7 か月 & & & \\
\hline 9 & 13 & 左陰囊腫大 & 左 3 & 1 年 2 か月 & & 正常 & 無 \\
\hline 10 & 14 & 左陰需腫大 & 左 3 & 2 年 & & & \\
\hline 11 & 15 & 左陰囊腫大 & 左 3 & 3 年 & & & \\
\hline 12 & 15 & 左陰霊腫大 & 右 2 左 3 & 3 年 & & & \\
\hline 13 & 15 & 左陰霊腫大 & 左 3 & 3 年 & & & \\
\hline 14 & 15 & 排尿痛 & 左 2 & 2 年 1 か月 & 腎孟腎炎 & 正常 & 無 \\
\hline 15 & 15 & 頻尿 & 左 3 & 3 か月 & 膀胱炎 & & \\
\hline 16 & 16 & 左陰震腫大 & 左 3 & 3 年 & & 正常 & 無 \\
\hline 17 & 17 & 左陰桽腫大 & 左 3 & 6 か月 & & 正常 & 無 \\
\hline 18 & 17 & 左陰囊腫大 & 左 3 & 11か月 & & & 無 \\
\hline 19 & 17 & 左陰囊痛 & 左 3 & 1 年 & 右副堂丸資 & & 無 \\
\hline 20 & 18 & 左陰襄腫大 & 左 3 & 1 か月 & 血精液症 & & \\
\hline
\end{tabular}


表 2 莘丸体積と組織所見

\begin{tabular}{|c|c|c|c|c|c|c|}
\hline & \multicolumn{2}{|c|}{ 殬丸体積 } & \multicolumn{2}{|c|}{ Sg./S.T.* } & \multicolumn{2}{|c|}{ score count ${ }^{* *}$} \\
\hline & 右 & 左 & 右 & 左 & 右 & 左 \\
\hline 1 & 1.9 & 1.2 & & & & \\
\hline 2 & 5.2 & 4.2 & & & & \\
\hline 3 & 4.1 & 2.0 & & & & \\
\hline 4 & 6.6 & 8.8 & 3.4 & 3.3 & 7.3 & 6.4 \\
\hline 5 & 14.1 & 8.4 & & & & \\
\hline 6 & 15.1 & 18.1 & 5.9 & 5.0 & 7.4 & 7.3 \\
\hline 7 & 4.6 & 4.9 & 2.5 & 3.5 & 4.5 & 6.0 \\
\hline 8 & 3.1 & 2.0 & & & & \\
\hline 9 & & & 5.8 & 4.7 & 6.0 & 5.9 \\
\hline 10 & 7.8 & 6.1 & & & & \\
\hline 11 & 19.2 & 20.0 & 10.8 & 8.7 & 5.0 & 6.6 \\
\hline 12 & 14.6 & 11.9 & & & & \\
\hline 13 & 10.8 & 10.8 & 7.8 & 6.7 & 4.5 & 5.6 \\
\hline 14 & 15.3 & 11.6 & 8.2 & 10.2 & 6.4 & 6.1 \\
\hline 15 & 13.8 & 12.1 & 12.4 & 9.6 & 7.4 & 6.6 \\
\hline 16 & 16.9 & 15.5 & 13.7 & 13.4 & 8.4 & 8.1 \\
\hline 17 & & & 10.8 & 8.8 & 6.8 & 7.1 \\
\hline 18 & & & 13.7 & 12.5 & 6.9 & 6.8 \\
\hline $19^{* * *}$ & $(4.5)$ & $(23.1)$ & - & 11.8 & - & 6.6 \\
\hline 20 & 13.7 & 12.2 & 14.5 & 15.0 & 7.4 & 5.9 \\
\hline
\end{tabular}

* spermatogonia/seminiferous tuble

** Jonsen's score count

*** right epididymitis

表 3 精液所見

\begin{tabular}{c|c|c|c}
\hline 症例 & $\begin{array}{c}\text { 精液量 } \\
(\mathrm{ml})\end{array}$ & $\begin{array}{c}\text { 精子数 } \\
\left(\times 10^{6} / \mathrm{ml}\right)\end{array}$ & $\begin{array}{c}\text { 運動率 } \\
(\%)\end{array}$ \\
\hline 16 & 3.3 & 67 & 64 \\
17 & 3.6 & 66 & 60 \\
19 & 3.0 & 38 & 58 \\
20 & 4.6 & 33 & 34 \\
\hline
\end{tabular}

(表 2 ).

精液所見は 16 歳以上の 4 例にて測定しえたが，ほぼ 正常の精子数, 精子運動率であった（表 3 ）.

\section{考案}

精索静脈瘤は従来より，成人に多くみられ小児には まれな疾患とされていた. Campbel1 $\left.{ }^{6}\right)$ は, 小児には精索 静脈瘤はまれで，これが存在することは一般に腹腔内 圧の異常を反映する，といっている．乙かし精索静脈 症は無症状のものが多く, 症状を怙こすものはその一 部のみと考えられる，成人では不妊症患者の中から発 見される率が高いため頻度が高くなるが，小児の場合 には何らかの症状を訴えて受診し，発見されるすのが 多いため，潜在患者は実際より多いと考学られる。一
般の小児に抢ける発生頻度についての本邦での報告は 見られないが， $\boldsymbol{~ s t e r ~}^{7}$ は1,072例の，6歳から19歳まで のデンマークの学童生徒を調べている.これによると， 10歳から19歳までの837例中136例 (16.2\%) にあった。 また Coolsaet ${ }^{8)}$ は精索静脈瘤67例のうち，10歳以下 5 例, 10 15歳43例を報告している. Heinz ${ }^{9}$ は，小児の 精索静脈瘤はめずらしいものではなく，これのピーク は15歳であるとしている。 また Horner ${ }^{10)} は, 14.5$ 歳か ら15歳での精索静脈瘤の頻度は $20.5 \%$ に達するといっ ている，成人に扔ける精索静脈瘤の頻度は，不妊症患 者に执いては， $19 \%^{11)} \sim 30 \%{ }^{12)}$ とかなり高率にみられ る.我々も1979年より1983年までの 5 年間に650例の不 妊患者中178例 (27.4\%) の精索静脈瘤をみている。 し かし一般成人に抢ける精索静脈瘤の頻度は Johnson $ら^{13)}$ は, 17歳から 24 歳の 1,592 人中 151 人( $\left.9.5 \%\right)$ にあっ たとしている。 また Lipshultz ら ${ }^{14)}$ は平均 25.2 歳の成 人82例中13例 $(13.8 \%$ ）と報告している。これらの数 字と比較した場合，小児に拈ける精索静脈瘤はまれな 疾患とはいえない。

辠丸の大きさは，その機能を反映していることはよ く知られている。肾の䁄丸の大きさは発育の状態が 個人差が大きいため，その絶対値を同じ年齢の正常小 児の平均と比較してもあまり意味がない.中村15) も, 思 春期に括ける臭丸の発育は個人的偏差が大きいので, 年齢相応に発育しているかどらかは18～19歳以上にな らないとわからないと述べている. Daniel ら ${ }^{16)}$ は50例 の正常な少年 $(10$ 13歳)の奠丸体積を測定し, $2 \sim 12$ $\mathrm{ml}$ とまちまちであった。 しかし個々の左右差を調べる と, 有意の差はなかったとしている，自験例では睪丸 の大きさが患側である左側が右に比べると有意に小さ かったことは，これが精索静脈瘤による影響と考兄ら れた。 また鋅丸組織所見では Jonsen の score count で は差はみられなかったが, 精祖細胞の数では有意の差 は示されなかったものの, 左の方が少かったものが多 く, 左の造精機能がより障害をうけていると考えられ た. 成人の精索静脈瘤では患側である左側だけでなく, 右側にも造精機能障害をきたしている，という報告が 多(17)18)が，小児では反対側への影響がまだ出てくる 前であるのかもしれない。

精液所見の結果でも例数は少ないが，いずれもほぼ 正常と考えられることより, 反対側における造精機能 障害は少ないものと考えられた。

小児の精索静脈瘤を処置しない場合の予後について は報告は少ない.Clarke ${ }^{19)}$ にれれ゙自然消失すること 
があるという. Steeno ら ${ }^{20)}$ は, 精索静脈瘤のはじめの ピークは15歳にあることを報告しているが，自験例で も12歳と 15 歳が最も多かった。このように精索静脈瘤 の発生頻度が年齢と共にかならずしも増えていないこ とからも自然消失することもあると考えられる。

しかし，多くの場合では自然消失することなく成人 に達し非可逆的な变化を与えてしまい，男子不妊症の 原因となる可能性があること，手術自体安全で確立さ れたものであること，小児の場合何らかの自覚症状を 持ったものが多く, 発見された時点で程度が強いもの が多いことなどの理由により，手術的に治療されるべ きものと考觉られた。

\section{文献}

1）川村健二：精索静脈瘤による男子不妊症の発生機 序. 千葉医学, 62, 33-39, 1986.

2）鈴木良徳：精索静脈瘤の研究.日泌尿会誌，58, 1105-1114, 1967.

3) Lambert, B.: The frequency of mumps and of mumps orchitis, and the consequences for sexuality and fertility, Acta genetica et statitica media, vol. 2. Suppl. 1. p. $68-70$, S. Karger, Basel, 1951.

4) Palomo, A.: Radical cure of varicocele by new technique : preliminary report. J. Urol., 61 , 604-607, 1949.

5) Jonsen, A.G.: Testicular biopsy scoure count: A method for registration of spermatogenesis in human testes: Normal values and results in 335 hypogonadal males. Hormones, 1, 2-25, 1970.

6) Campbell, M.F.: The male genital tract and the female urethra. In Urology, Campbell, M.F. and Harrison, J.H., 3rd ed. p. 1861-1862, Saunders, Co., Philadelphia, 1970.

7) Фster, J. : Varicocele in children and adolescents : An investigation of the incedence among Danish school children. Scan. J. Urol. Nephrol., 5, 27-32, 1971.

8) Coolsaet, B.L.R.A.: The varicocele syndrome: Venography determining the optimal level for surgical management. J. Urol., 124,
833-839, 1980.

9) Heinz, H.A., Voggenthaler, J. and Weissbach, L. : Histological findings in testes with varicocele during childhood and their their therapeutic consequences. Eur. J. Pediatr., 133, 139-146, 1980.

10) Horner, J.S. : The varicocele. Medical Officer, 104, 377-381, 1960.

11) Hendry, W.F., Sommerville, I.F., Hall, R.R. and Pugh, R.C.B. : Investigation and treatment of the subfertile male. Br. J. Urol., 45, 684-692, 1973.

12) Dubin, L. and Amelar, R.D.: Etiological factors in 1294 consecutive cases of male infertility. Fertil. Steril., 22, 469-474, 1971.

13) Johnson, D.E., Pohl, D.R. and Rivera-Correa, H.: Varicocele: An innocuous condition?. South, Med. J., 63, 34-36, 1970.

14) Lipshultz, L.I. and Corriere, J.N. Jr. : Progressive testicular atrophy in the varicocele patients. J. Urol., 117, 175-176, 1977.

15）中村 亮: 日本人男子の性器系の発育と成熟. 日 泌尿会誌，52，172-188，1961.

16) Daniel, W.A. Jr., Feinstein, R.A., Howard-Peebles, P. and Baxley, W.D.: Clinical and laboratory observations: Tisticular volumes of adolescents. J. Pediatr., 101，1010-1012， 1982.

17) Etriby, A., Girgis, S.M., Hefnawy, H. and Ibrahim, A.A.: Tisticular changes in subfertile males with varicocele. Fertil. Steril., 18, 666-671, 1967.

18) Dubin, L. and Hotchkiss, R.S.: Testes biopsy in subfertile men with varicocele. Fertil. Steril., 20, 50-57, 1969.

19) Clarke, B.G.: Incedence of varicocele in normal men and among men of different ages. J.A. M.A., 198, 195-196, 1966.

20) Steeno, O., Knops, J., Declerck, L., Adimoelja, A. and Velde, H.: Prevention of fertility disorders by detection an and treatment of varicocele at school and collage age. Androgia, 8, 47-53, 1976.

（1986年 3 月 28 日受付） 